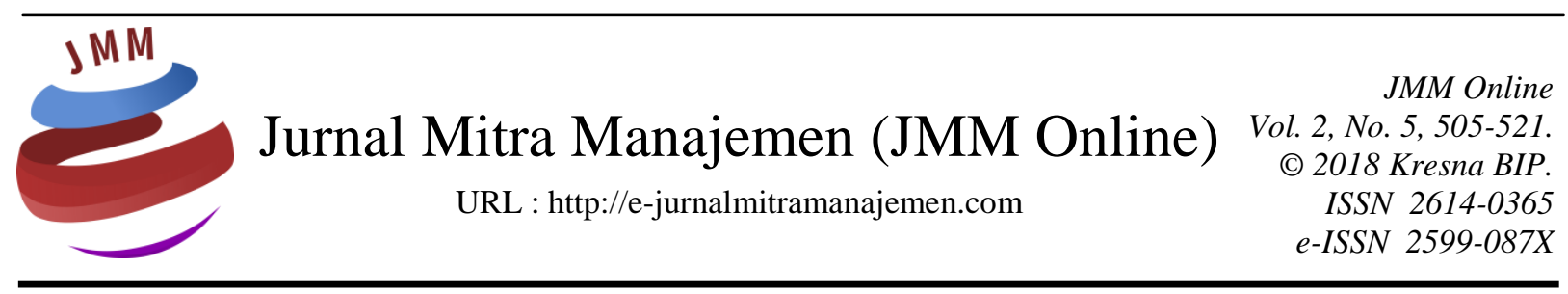

\title{
IMPLEMENTASI KETERAMPILAN MENGADAKAN VARIASI \\ PADA PRAKTIK PENGALAMAN LAPANGAN MAHASISWA PROGRAM STUDI PENDIDIKAN BAHASA INGGRIS STKIP PGRI BANJARMASIN
}

\author{
Vivi Aulia \\ STKIP PGRI Banjarmasin
}

\section{INFORMASI ARTIKEL}

Dikirim : 10 September 2018

Revisi pertama : 12 September 2018

Diterima : 14 September 2018

Tersedia online : 28 September 2018

Kata Kunci : Implementasi,

Keterampilan Mengadakan Variasi,

Praktik Pengalaman Lapangan

Email : viviauliavasa@yahoo.com

\section{ABSTRAK}

Penelitian ini bertujuan untuk mengetahui implementasi keterampilan mengadakan variasi pada Praktik Pengalaman Lapangan mahasiswa Program Studi Pendidikan Bahasa Inggris STKIP PGRI Banjarmasin. Subyek penelitian ini adalah lima orang mahasiswa yang melaksanakan praktik mengajar di SMAN 5 Banjarmasin, MAN 3 Banjarmasin, dan SMKN 1 Banjarmasin. Data penelitian digali dengan menggunakan lembar observasi yang memuat indikator keterampilan mengadakan variasi yang ditampilkan mahasiswa. Selain itu, catatan lapangan digunakan dalam merekam pengamatan untuk mendukung hasil yang belum tercantum pada lembar observasi. Hasil penelitian ini menunjukkan bahwa kelima mahasiswa praktik menampilkan keterampilan mengadakan variasi pada aspek penggunaan variasi suara, gerak dan mimik, kesenyapan guru, variasi dalam penggunaan media pembelajaran visual, serta variasi dalam pola interaksi satu arah dari guru kepada peserta didik. Masih banyak terdapat keterampilan mengadakan variasi lain yang belum dilakukan. Diperlukan evaluasi bersama antara dosen pembimbing PPL, guru pamong di sekolah praktik, kepala sekolah dan mahasiswa praktik itu sendiri untuk merancang dan menerapkan proses pembelajaran yang optimal. 


\section{PENDAHULUAN \\ Latar Belakang}

Menguasai teori dan konsep pengajaran serta menerapkannya dalam kegiatan pengajaran dan pembelajaran merupakan kemampuan yang mutlak harus dimiliki oleh seorang pengajar. Mengajar peserta didik merupakan kegiatan yang kompleks. Sebagai salah satu profesi yang berkaitan dengan pengajaran dan pembelajaran, guru menjadi komponen utama penentu keberlangsungan kegiatan belajar dan mengajar. Disamping faktor guru sebagai subyek yang mengajar, terdapat faktor-faktor lain yang turut berkontribusi memainkan peran penting dalam keberhasilan proses pembelajaran, diantaranya: faktor peserta didik itu sendiri sebagai obyek yang diajar, lingkungan belajar, pengelolaan kelas, keterampilan guru dalam mengajar, dan sebagainya.

Pembelajaran dipandang sebagai suatu sistem instruksional yang terdiri dari seperangkat komponen-komponen yang saling mendukung untuk mencapai tujuan tertentu. Pembelajaran meliputi komponen-komponen yang tidak dapat dipisahkan satu sama lain, yaitu tujuan pembelajaran, bahan ajar, metode pembelajaran, situasi pembelajaran, serta evaluasi pembelajaran (Asril, 2013:18). Ketika guru berada dalam kelas untuk melaksanakan proses pembelajaran, ia tidak boleh hanya memperhatikan satu komponen saja. Akan tetapi, komponen lainnya harus dipertimbangkan secara keseluruhan. Setiap komponen akan saling mendukung komponen yang lainnya. Dalam usaha memaksimalkan dan mengintegrasikan semua komponen pembelajaran tersebut, maka seorang guru dituntut untuk menguasai keterampilan mengajar (teaching skill) untuk kemudian diterapkan di dalam kelas. Dengan demikian, tujuan pembelajaran akan dapat dicapai dengan efektif karena kesinambungan antar komponen pembelajaran tersebut.

STKIP PGRI Banjarmasin sebagai salah satu institusi pendidikan tinggi di Kalimantan Selatan di bidang keguruan memiliki visi untuk mempersiapkan dan menghasilkan lulusan yang kompeten di bidang pengajaran, pembelajaran, dan pengelolaan pendidikan. Mahasiswa diberikan bekal pengetahuan dan keilmuan yang berkaitan dengan keguruan sejak di semester awal. Salah satu mata kuliah yang diberikan kepada mahasiswa mengenai prinsip dan teori pengajaran adalah Praktik Pengalaman Lapangan (PPL). Mata kuliah ini diberikan selama dua semester yaitu Praktik Pengalaman Lapangan (PPL) I dan II.

Secara rinci, pada mata kuliah Praktik Pengalaman Lapangan (PPL) I, mahasiswa sebagai calon guru diberikan pengetahuan mengenai pembelajaran mikro (micro teaching) serta mempraktekkannya. Tujuan pembelajaran mikro ini adalah melatih calon guru agar memiliki keterampilan dasar dan khusus yang menunjang proses pembelajaran (Pedoman Praktik Pengalaman Lapangan STKIP PGRI Banjarmasin, 2017). Hal ini sejalan dengan penjelasan Asril (2013:46) bahwa sasaran akhir yang akan dicapai dalam pembelajaran micro teaching adalah calon guru memiliki pengetahuan tentang proses pembelajaran, terampil dalam proses pembelajaran, serta memiliki perilaku yang baik sebagai seorang guru.

Setelah mahasiswa melakukan praktik pengajaran mikro di mata kuliah PPL I, selanjutnya mahasiswa diharuskan untuk praktik mengajar di kelas yang sesungguhnya pada jenjang SMP dan SMA sederajat sebagai kegiatan Praktik Pengalaman Lapangan II (PPL II). Tujuan praktik mengajar di sekolah yang sesungguhnya adalah 
memberikan pengalaman belajar secara langsung dengan merealisasikan pengetahuan dan pembelajaran mikro yang sudah didapat sebelumnya di kegiatan PPL I. Dengan demikian, mahasiswa tidak hanya sekedar memperoleh pengetahuan mengenai pembelajaran secara teoritis saja, tetapi mereka dapat mempraktekkan teori pengajaran tersebut secara praksis di kelas yang nyata.

Pada praktik pengajaran mikro di mata kuliah PPL I, mahasiswa diberikan pengetahuan mengenai keterampilan dasar mengajar. Menurut Suwarna dkk (2013:209), terdapat sepuluh keterampilan dasar mengajar yang diberikan kepada mahasiswa sesuai yaitu: (1) keterampilan menyusun skenario pembelajaran, (2) keterampilan membuka dan menutup pelajaran, (3) keterampilan menjelaskan, (4) keterampilan bertanya, (5) keterampilan memberikan penguatan, (6) keterampilan menggunakan media dan alat, (7) keterampilan mengadakan variasi, (8) keterampilan membimbing diskusi, (9) keterampilan melakukan penilaian, dan (10) keterampilan mengelola kelas. Semua keterampilan tersebut mutlak harus dipelajari dan dikuasai oleh calon guru sehingga mereka dapat menjalankan proses pembelajaran dengan terstruktur dan profesional.

Diantara sepuluh keterampilan dasar mengajar tersebut diatas, salah satu keterampilan yang dipandang cukup sulit adalah keterampilan mengadakan variasi. Keterampilan ini berkaitan dengan kegiatan guru dalam konteks proses interaksi pembelajaran yang dilakukan untuk mengurangi kebosanan peserta didik, sehingga dalam proses pembelajaran, para peserta didik menunjukkan partisipasi dan keterlibatan aktif. Keterampilan variasi yang dapat dilakukan dalam proses pembelajaran terbagi menjadi tiga kelompok besar, antara lain: variasi dalam gaya guru mengajar, variasi dalam pola interaksi guru dengan peserta didik, serta variasi dalam menggunakan media dan alat-alat pembelajaran.

Secara spesifik, keterampilan mengadakan variasi ini harus dapat menumbuhkan minat belajar peserta didik serta mengurangi ketegangan dan tekanan akan situasi pembelajaran didalam kelas. Keterampilan mengadakan variasi ini dapat dilakukan dengan memodifikasi suara guru (voice variations), menggunakan isyaratisyarat non verbal seperti pandangan mata (eye contact), roman muka (facial expression), gerak-gerik tangan (gesture), serta perpindahan posisi guru dalam berdiri dikelas (movement).

Selain itu, variasi dalam pola interaksi guru dan peserta didik dapat dilakukan dengan cara mengatur frekuensi yang seimbang antara kapan guru harus menjelaskan materi di depan kelas dan kapan guru harus memberikan kegiatan belajar secara intensif kepada peserta didik. Guru tidak harus terlalu banyak menghabiskan durasi waktu mengajar untuk berdiri di depan kelas menjelaskan materi yang berpotensi mengakibatkan peserta didik kehilangan perhatian. Akan tetapi, guru harus bisa mengatur ritme mengajar dengan pemberian latihan, tugas, diskusi, presentasi, unjuk penampilan, dan kegiatan belajar lainnya.

Dalam hal variasi penggunaan media dan alat-alat pembelajaran, guru dapat menggunakan berbagai benda dan bahan yang memungkinkan untuk menunjang kegiatan pembelajaran, seperti laptop, LCD, gambar-gambar visual, video, alat peraga, rekaman suara, maupun alat-alat lainnya. Guru diharuskan untuk kreatif dan tidak 
hanya mengandalkan papan tulis saja, sehingga variasi dalam penggunaan media seperti ini akan menambah antusiasme dan keingintahuan peserta didik dalam belajar.

Keterampilan mengadakan variasi menjadi bagian dari keterampilan dasarmengajar yang harus dikuasai oleh calon guru. Mahasiswa Program Studi Pendidikan Bahasa Inggris STKIP PGRI Banjarmasin yang telah diberikan pembekalan dan latihan pada praktik pengajaran mikro sudah seharusnya dapat mengimplementasikan keterampilan ini pada saat mereka melakukan praktik pengalaman lapangan di kelas yang nyata. Oleh karena itu, tujuan penelitian ini adalah mengetahui implementasi keterampilan mengadakan variasi pada praktik pengalaman mahasiswa Program Studi Pendidikan Bahasa Inggris STKIP PGRI Banjarmasin mengajar pada jenjang SMA sederajat.

\section{KAJIAN PUSTAKA}

Kajian pustaka penelitian ini meliputi konsep pembelajaran, keterampilan dasar mengajar, dan pelaksanaan Program Praktik Pengalaman Lapangan yang dilaksanakan di STKIP PGRI Banjarmasin.

\section{Konsep Pembelajaran}

Menurut Undang-Undang Nomor 20 Tahun 2003 tentang Sistem Pendidikan Nasional, Bab I Ketentuan Umum Pasal 1 ayat 20, pembelajaran adalah proses interaksi peserta didik dengan pendidik dan sumber belajar pada suatu lingkungan belajar. Pembelajaran bisa dipahami sebagai suatu rangkaian kegiatan yang melibatkan komponen pembelajaran untuk mencapai suatu tujuan tertentu. Komponen pembelajaran disini merupakan satu kesatuan elemen yang dipadukan secara harmonis agar tercapai tujuan pembelajaran itu sendiri. Dengan demikian, pembelajaran merupakan perpaduan antara kegiatan mengajar yang dilakukan oleh guru dan kegiatan belajar yang dilakukan oleh peserta didik untuk menciptakan pengalaman belajar yang memungkinkan peserta didik untuk melalui, mengalami dan memperoleh pengetahuan, pemahaman, pembentukan sikap dan keterampilan (Helmiati,2013:2-3).

Pembelajaran mengandung kegiatan belajar dan mengajar. Belajar merupakan sebuah proses mempelajari sesuatu yang dilakukan oleh peserta didik baik secara individu maupun berkelompok. Sementara itu, mengajar bisa diartikan sebagai sebuah kegiatan untuk mentransfer ilmu dan pengetahuan oleh guru kepada peserta didik sehingga terjadi proses perubahan dalam dirinya untuk mencapai tujuan tertentu. Berdasarkan deskripsi diatas, maka pembelajaran merupakan sebuah proses dan kegiatan dua arah yang berkesinambungan yaitu kegiatan dari pihak yang mengajar (guru) serta kegiatan dari pihak yang belajar (peserta didik). Oleh karena itu, pembelajaran merupakan satu kesatuan kegiatan yang tidak dapat dipisahkan anatara satu komponen dengan komponen lainnya.

Untuk mewujudkan proses pembelajaran yang seimbang dan berkesinambungan, terdapat lima komponen dasar yang berperan dan mendukung terlaksananya hal tersebut. Kelima komponen tersebut diantaranya tujuan mengajar, materi pembelajaran, metode dan teknik pembelajaran, perlengkapan, media, dan fasilitas pembelajaran, serta evaluasi (penilaian) pembelajaran (Asril, 2013:2). Kelima komponen tersebut berperan penting dalam mewujudkan proses pembelajaran yang 
optimal. Dengan demikian, proses pembelajaran tidak hanya ditentukan oleh factor pelaku pembelajaran itu sendiri yaitu guru dan peserta didik. Akan tetapi, pembelajaran melibatkan semua aspek yang harus diusahakan secara maksimal agar tercapai tujuan yang diinginkan.

\section{Pengenalan Keterampilan Dasar Mengajar}

Pembelajaran dan pengajaran merupakan aktifitas yang kompleks. Menjadi pengajar profesional tidak cukup hanya dengan bermodalkan ijazah pendidikan di bidang keguruan. Secara nyata, seorang pengajar diharuskan menguasai ilmu-ilmu pendidikan dan pengajaran. Akan tetapi, menguasai ilmu-ilmu pendidikan dan pengajaran saja tidaklah cukup. Keterampilan mengimplementasikan ilmu-ilmu pendidikan dan pengajaran ke dalam sebuah proses pembelajaran menjadi syarat mutlak yang harus dimiliki oleh seorang pengajar.

Dalam kaitannya dengan penguasaan dan pengimplementasian ilmu-ilmu pendidikan dan pengajaran ke dalam sebuah proses pembelajaran, seorang calon guru harus mempelajari keterampilan dasar mengajar terlebih dahulu. Keterampilan dasar mengajar ini menjadi penting harus dilatih dan dikuasai karena seorang pengajar memiliki peran penting dalam implementasi pembelajaran. Suwarna dkk (2013:208209) menekankan bahwa terdapat dua kemampuan pokok yang harus dikuasai oleh seorang pengajar yaitu menguasai materi atau bahan ajar yang akan diajarkan (what to teach) dan menguasai metode atau cara untuk membelajarkannya (how to teach). Dalam hal ini, menguasai keterampilan dasar mengajar termasuk dalam kemampuan pokok yang kedua yaitu cara untuk membelajarkan peserta didik.

Asril (2013:68-90) dan Helmiati (2013:43-88) mengemukakan bahwa terdapat delapan keterampilan dasar mengajar yang harus dikuasai oleh seorang calon pengajar. Secara umum, masing-masing keterampilan dasar mengajar tersebut dideskripsikan sebagai berikut:

\section{Keterampilan Membuka dan Menutup Pembelajaran (Set Induction and Closure)}

Keterampilan membuka pelajaran merupakan usaha yang dilakukan guru dalam kegiatan pembelajaran untuk menciptakan kondisi bagi peserta didik agar mental, perhatian, serta konsentrasi terpusat pada apa yang akan dipelajari, sehingga usaha tersebut akan memberikan efek positif terhadap kegiatan belajar. Dalam kegiatan membuka pelajaran, guru diharapkan memberikan motivasi kepada peserta didik sehingga mereka memiliki kemauan dan semangat dalam belajar. Sementara itu, kegiatan menutup pelajaran merupakan keterampilan merangkum inti pelajaran pada akhir kegiatan belajar.

\section{Keterampilan Menjelaskan Pelajaran (Explaining)}

Keterampilan menjelaskan pelajaran merupakan keterampilan guru dalam menyampaikan bahan pelajaran kepada peserta didik secara lisan yang diorganisasikan secara terencana dan sistematis sehingga semua bahan pelajaran tersebut dapat dipahami oleh peserta didik dengan mudah.

\section{Keterampilan Bertanya (Questioning)}

Keterampilan bertanya merupakan keterampilan guru dalam memberikan pertanyaan sebagai bagian dari menstimulasi peserta didik untuk memberikan respon 
terhadap bahan pelajaran yang sedang atau sudah dipelajari. Jenis-jenis pertanyaan yang diberikan guru, diantaranya: pertanyaan permintaan (compliance question), pertanyaan retoris (rhetorical question), pertanyaan mengarahkan (prompting question), pertanyaan menggali (probing question), pertanyaan yang menggunakan konsep taksonomi Bloom, serta pertanyaan lain yang luas dan sempit sasarannya.

\section{Keterampilan Mengadakan Variasi (Variation Stimulus)}

Keterampilan mengadakan variasi berarti melakukan tindakan yang beraneka ragam yang membuat sesuatu menjadi tidak monoton didalam pembelajaran sehingga tidak menimbulkan rasa bosan, sehingga peserta didik senantiasa menunjukkan ketekunan, antusiasme, serta penuh partisipasi. Didalam proses belajar mengajar, variasi yang dilakukan guru ditunjukkan dalam bentuk variasi gaya mengajar, variasi dalam penggunaan media dan alat pembelajaran, serta variasi dalam bentuk pola interaksi dan aktivitas peserta didik.

\section{Keterampilan Memberikan Penguatan (Reinforcement)}

Keterampilan memberikan penguatan merupakan keterampilan guru dalam memberikan segala bentuk respons, baik verbal maupun non verbal, yang merupakan bagian dari modifikasi tingkah laku guru terhadap tingkah laku peserta didik, yang bertujuan memberikan informasi atau umpan balik.

\section{Keterampilan Mengelola Kelas (Classroom Management)}

Keterampilan mengelola kelas merupakan usaha guru dalam menciptakan dan memelihara kondisi belajar yang optimal untuk mencapai tujuan pembelajaran. Keterampilan ini meliputi kegiatan pengaturan kelas yang berkaitan dengan penyampaian materi atau penyediaan kondisi belajar.

\section{Keterampilan Mengajar Kelompok Kecil dan Perseorangan}

Terdapat empat komponen keterampilan yang harus dimiliki oleh guru untuk pengajaran kelompok kecil dan perorangan. Keempat keterampilan tersebut adalah mengadakan pendekatan secara pribadi, mengorganisasikan, membimbing dan memudahkan belajar, serta merencanakan dan melaksanakan kegiatan belajar mengajar.

\section{Keterampilan Memimpin Diskusi Kelompok Kecil (Guiding Small Discussion)}

Keterampilan memimpin diskusi kelompok kecil merupakan keterampilan yang melibatkan sekelompok orang dalam berinteraksi untuk saling belajar, berbagi pengalaman, pengambilan kesimpulan, atau pemecahan masalah. Keterampilan yang harus dimiliki guru terkait membimbing diskusi kelompok kecil yaitu memusatkan perhatian, memperjelas masalah urun pendapat, menganalisis pandangan peserta didik, menyebarkan kesempatan berpartisipasi, serta menutup diskusi.

\section{Pelaksanaan Program Praktik Pengalaman Lapangan di STKIP PGRI Banjarmasin}

STKIP PGRI Banjarmasin merupakan salah satu LPTK (Lembaga Pendidikan Tenaga Kependidikan) di Kalimantan Selatan yang memiliki visi dan misi mencetak tenaga pendidik dan kependidikan yang profesional. Dalam usaha mewujudkan visi dan misi tersebut, para mahasiswa dibekali pendidikan keguruan yang bertujuan untuk menghasilkan lulusan yang mampu melaksanakan tugas-tugas kependidikan secara mandiri dan profesional setelah mereka nantinya bekerja sebagai guru atau tenaga 
kependidikan. Dalam usaha mencapai visi dan misi yang ditentukan, STKIP PGRI Banjarmasin memberikan mata kuliah Praktik Pengalaman Lapangan (PPL) yang wajib diikuti oleh mahasiswa pada semua program studi tanpa terkecuali.

Mata kuliah PPL yang terdapat di STKIP PGRI Banjarmasin dilaksanakan selama dua semester yaitu tersaji di semester VI dan VII pada semua program studi, sehingga pelaksanaannya serentak dan bersama-sama. Kegiatan PPL ini dikoordinir dan dikelola oleh Unit Program Pengalaman Lapangan (UPPL) STKIP PGRI Banjarmasin yang memiliki fungsi sebagai unit yang mengatur dan mengkoordinir segala kegiatan yang berkaitan dengan PPL mahasiswa. Semua mahasiswa yang telah memenuhi persyaratan secara administratif maupun akademik wajib mengikuti kegiatan PPL ini secara tuntas dari awal hingga akhir.

Mata kuliah Praktik Pengalaman Lapangan (PPL) yang terdapat pada STKIP PGRI Banjarmasin dimaksudkan sebagai sarana bagi mahasiswa untuk dapat mengukur kemampuannya dalam mengaplikasikan seluruh pengetahuan yang didapatnya selama duduk di bangku kuliah. Selain itu, kegiatan PPL ini juga menjadi sarana latihan bagi mahasiswa sebagai calon guru agar nantinya setelah lulus dapat menjadi guru yang profesional (Pedoman Praktik Pengalaman Lapangan STKIP PGRI Banjarmasin, 2017:1). Mata kuliah PPL di STKIP PGRI Banjarmasin disajikan dalam dua semester yaitu Praktik Pengalaman Lapangan I (PPL I) yang disajikan pada semester VI dan Praktik Pengalaman Lapangan II (PPL II) yang disajikan pada semester VII.

Praktik Pengalaman Lapangan I (PPL I) dilaksanakan di kampus dalam bentuk perkuliahan tatap muka yang didalamnya terdapat praktik micro teaching dan ditambah dengan kegiatan observasi di sekolah-sekolah praktik yang telah ditunjuk oleh UPPL. Secara teoritis, perkuliahan tatap muka ini memberikan bekal teori dalam kaitannya dengan pengenalan kurikulum, keterampilan dasar mengajar, model-model pembelajaran, jenis-jenis media pembelajaran, penyusunan perangkat pembelajaran, evaluasi pembelajaran, manajemen kelas, dan sebagainya.

Setelah selesai perkuliahan secara teori, mahasiswa melaksanakan praktik keterampilan mengajar terbatas dalam bentuk mikro (micro teaching). Dalam penyelenggaraannya, PPL I dilaksanakan dalam bentuk peer teaching yaitu mahasiswa yang sedang melaksanakan latihan mengajar menampilkan simulasi mengajarnya kepada teman sekelasnya. Dosen pengampu mata kuliah PPL I dan teman sekelas akan mengobservasi dan memberikan umpan balik diakhir kegiatan simulasi tersebut. Hasil umpan balik kemudian didiskusikan dan dibahas bersama-sama dikelas untuk mengetahui kekurangan pada simulasi yang dilakukan mahasiswa.

Selanjutnya, pada Praktik Pengalaman Lapangan II (PPL II) yang dilaksanakan di semester VII mahasiswa melaksanakan praktik mengajar yang nyata di sekolahsekolah yang ditunjuk oleh UPPL STKIP PGRI Banjarmasin. Praktik mengajar ini dilaksanakan selama kurang lebih dua bulan pada jenjang SMP dan SMA sederajat yang telah ditentukan. Syarat untuk mengikuti kegiatan PPL II ini adalah telah lulus pada PPL I yang dilaksanakan sebelumnya. Praktik mengajar PPL II yang dilaksanakan mahasiswa akan dinilai oleh dosen pembimbing PPL II yang ditunjuk serta guru pamong mata pelajaran di sekolah praktik. Selama proses kegiatan PPL II, mahasiswa membuat perangkat pembelajaran yang dikonsultasikan kepada guru 
pamong mata pelajaran dan dosen pembimbing. Diakhir kegiatan PPL II, mahasiswa membuat laporan kegiatan PPL II yang berisikan semua kegiatan praktik mengajar yang telah dilakukan selama kurang lebih dua bulan berada di sekolah praktik tersebut.

\section{METODE PENELITIAN}

Penelitian ini menggunakan pendekatan deskriptif kualitatif. Subyek yang diteliti adalah mahasiswa semester VII angkatan 2014 Program Studi Pendidikan Bahasa Inggris STKIP PGRI Banjarmasin yang sedang menjalankan PPL II di sekolah-sekolah jenjang SMP dan SMA sederajat yang ditunjuk oleh pihak UPPL STKIP PGRI Banjarmasin pada tahun pelajaran 2017-2018. Penelitian dilakukan selama dua bulan yaitu pada bulan September hingga November 2017. Waktu penelitian ini menyesuaikan dengan pelaksanaan PPL II yang waktunya telah disesuaikan dengan kalender akademik sekolah praktik. Setiap mahasiswa yang melaksanakan PPL II didampingi oleh dosen pembimbing yang telah ditunjuk dan guru pamong dari sekolah praktik. Tugas dosen pembimbing dan guru praktek adalah bekerjasama, bersinergi, serta melakukan penilaian bersama-sama atas praktik mengajar yang dilakukan oleh mahasiswa. Dalam penelitian ini, peneliti juga ditunjuk sebagai dosen pembimbing PPL II, sehingga mahasiswa yang diteliti adalah mahasiswa dibawah bimbingan peneliti sebagai dosen pembimbing PPL II.

Mahasiswa yang menjadi obyek penelitian ini adalah lima orang mahasiswa yang tersebar untuk praktik mengajar di jenjang SMA sederajat yaitu satu orang yang praktik mengajar di SMAN 5 Banjarmasin (guru A), dua orang yang praktik mengajar di MAN 3 Banjarmasin (guru B dan guru C), serta dua orang yang praktik mengajar di SMKN 1 Banjarmasin (guru D dan guru E). Teknik pengumpulan data pada penelitian ini menggunakan lembar observasi atau pengamatan yang berisi semua komponen keterampilan mengadakan variasi didalam kelas yang diisi berdasarkan penampilan mahasiswa ketika praktik mengajar. Format lembar observasi yang digunakan tertera pada Tabel 1 berikut.

Tabel 1. Lembar Pengamatan Mahasiswa Pada PPL II Lembar Pengamatan

Mahasiswa PPL II Keterampilan Mengadakan Variasi (Variation Stimulus)

Nama mahasiswa

Tempat praktik

Kelas

\begin{tabular}{|c|c|c|c|c|}
\hline No & Indikator & Karakteristik & $\begin{array}{c}\text { Nampak/Tidak } \\
\text { (diisi dengan } \\
\text { tanda centang) }\end{array}$ & Persentase \\
\hline \multirow{6}{*}{1} & \multirow{6}{*}{$\begin{array}{l}\text { Variasi } \\
\text { pada gaya } \\
\text { mengajar }\end{array}$} & $\begin{array}{l}\text { Penggunaan variasi suara (teacher voice): } \\
\text { nada suara, volume suara, kecepatan bicara }\end{array}$ & & \\
\hline & & Pemusatan perhatian peserta didik (focusing) & & \\
\hline & & $\begin{array}{l}\text { Gerak (movement) dan mimik: gerakan tangan } \\
\text { dan badan untuk memperjelas materi }\end{array}$ & & \\
\hline & & $\begin{array}{l}\text { Kontak pandang (eye contact): melayangkan } \\
\text { pandangan ke seisi kelas }\end{array}$ & & \\
\hline & & $\begin{array}{l}\text { Kesenyapan atau kebisuan guru (teacher } \\
\text { silence): memberikan waktu senyap }\end{array}$ & & \\
\hline & & $\begin{array}{l}\text { Pergantian posisi guru dalam kelas dan gerak } \\
\text { guru (teacher movement) }\end{array}$ & & \\
\hline
\end{tabular}


Lanjutan Tabel 1. Lembar Pengamatan Mahasiswa Pada PPL II Lembar Pengamatan Mahasiswa PPL II Keterampilan Mengadakan Variasi (Variation Stimulus)

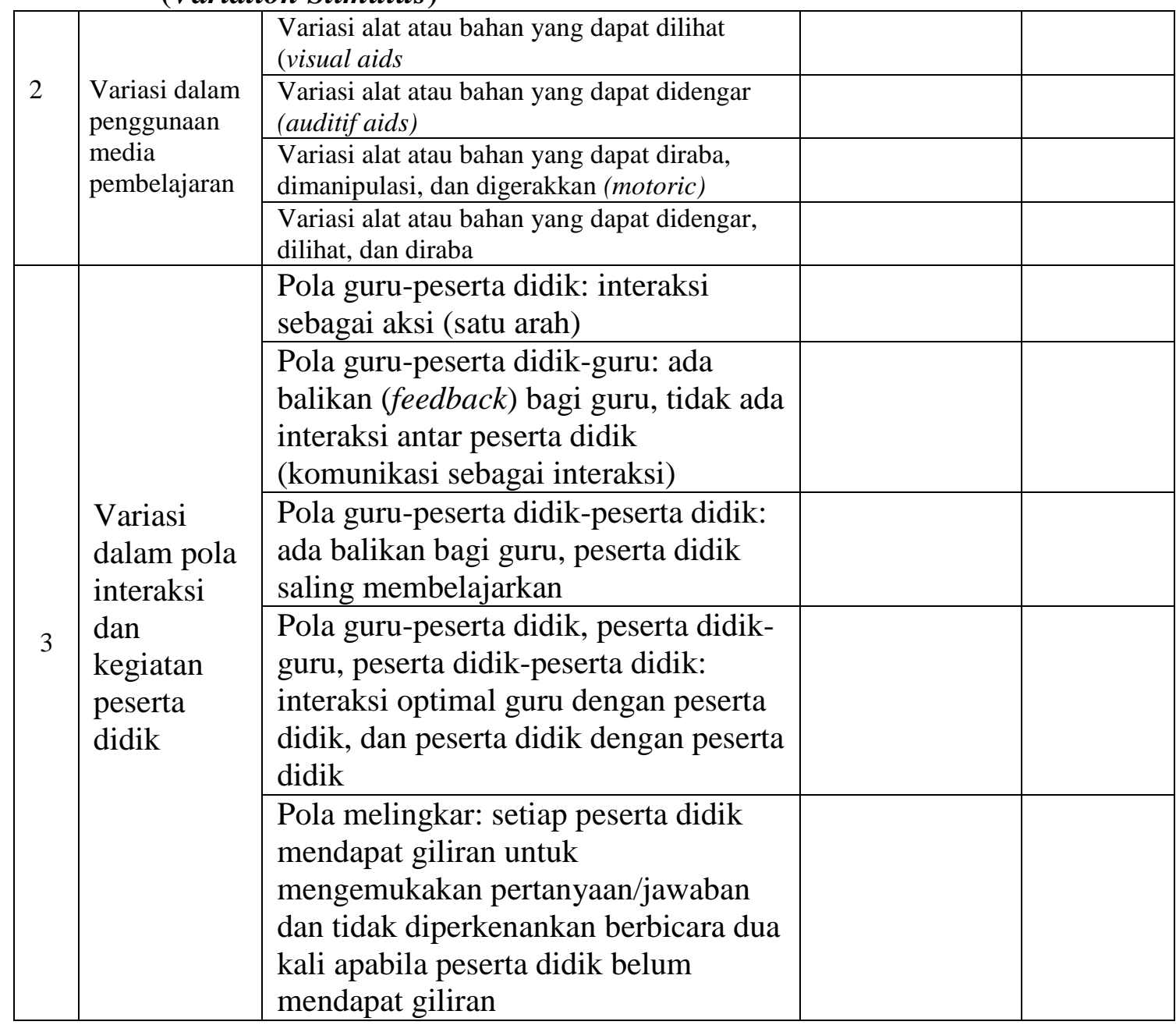

Sumber : Asril (2013:158) dan Ambarawati (2016:85)

Selain menggunakan lembar observasi seperti tertera pada Tabel 1, peneliti juga menggunakan lembar catatan lapangan (field notes) yang digunakan sebagai instrumen tambahan untuk mencatat dan merekam keterampilan mengadakan variasi yang belum terekam pada lembar observasi. Lembar catatan lapangan ini diisi dengan deskripsi tambahan yang mungkin muncul selama pelaksanaan observasi, sehingga peneliti mendapatkan data yang lebih lengkap sebagai bahan untuk dianalisis lebih lanjut.

Data yang terkumpul dalam lembar observasi dan catatan lapangan selanjutnya dianalisis dengan menggunakan konsep dari Miles dan Huberman yaitu reduksi data, penyajian data, dan penarikan kesimpulan. Dalam reduksi data, peneliti melakukan seleksi atas data yang terkumpul. Apabila data sudah dianggap cukup, maka peneliti memberikan kode tertentu. Data hasil observasi dengan menggunakan Tabel 1 disajikan dalam bentuk tabel dan dihitung persentase setiap karakteristik keterampilan mengadakan variasi yang muncul pada penampilan PPL II mahasiswa. Setelah itu, 
penarikan kesimpulan dilakukan dengan melihat sajian analisis akhir data dengan menggali pembahasan berdasarkan kajian teori dan literatur.

\section{HASIL PENELITIAN DAN PEMBAHASAN}

\section{Hasil Penelitian}

Berikut ini disajikan hasil penelitian yang sumber datanya berasal dari lembar observasi yang digunakan untuk mengamati penampilan lima orang mahasiswa dalam praktik mengajar PPL II untuk keterampilan mengadakan variasi dalam proses pembelajaran Bahasa Inggris. Selain itu, hasil penelitian juga merangkum data tambahan yang bersumber dari catatan lapangan.

\section{Hasil Penampilan Mahasiswa PPL II pada Keterampilan Mengadakan Variasi berdasarkan Pengamatan}

Hasil dari lima orang mahasiswa Program Studi Pendidikan Bahasa Inggris STKIP PGRI Banjarmasin yang melaksanakan praktik mengajar pada PPL II di jenjang SMA sederajat ditampilkan pada Tabel 2 berikut.

Tabel 2. Hasil Penampilan Mahasiswa pada Keterampilan Mengadakan Variasi

\begin{tabular}{|c|c|c|c|c|c|c|c|c|}
\hline \multirow{3}{*}{ No } & \multirow{3}{*}{ Indikator } & \multirow{3}{*}{ Karakteristik } & \multirow{2}{*}{\multicolumn{5}{|c|}{$\begin{array}{c}\text { Nampak/Tidak } \\
\text { Kode Guru }\end{array}$}} & \multirow{3}{*}{ Persentase } \\
\hline & & & & & & & & \\
\hline & & & $\mathbf{A}$ & B & $\mathbf{C}$ & D & $\mathbf{E}$ & \\
\hline \multirow{6}{*}{1} & \multirow{6}{*}{$\begin{array}{l}\text { Variasi pada } \\
\text { gaya } \\
\text { mengajar }\end{array}$} & $\begin{array}{l}\text { Penggunaan variasi suara } \\
\text { (teacher voice): nada suara, } \\
\text { volume suara, kecepatan bicara }\end{array}$ & V & - & V & V & V & $80 \%$ \\
\hline & & $\begin{array}{l}\text { Pemusatan perhatian peserta } \\
\text { didik (focusing) }\end{array}$ & $\mathrm{V}$ & - & - & - & - & $20 \%$ \\
\hline & & $\begin{array}{l}\text { Gerak (movement) dan mimik: } \\
\text { gerakan tangan dan badan untuk } \\
\text { memperjelas materi }\end{array}$ & $\mathrm{V}$ & $\mathrm{V}$ & $\mathrm{V}$ & $\mathrm{V}$ & $\mathrm{V}$ & $100 \%$ \\
\hline & & $\begin{array}{l}\text { Kontak pandang (eye contact): } \\
\text { melayangkan pandangan ke seisi } \\
\text { kelas }\end{array}$ & $\mathrm{V}$ & - & - & $\mathrm{V}$ & $\mathrm{V}$ & $60 \%$ \\
\hline & & $\begin{array}{l}\text { Kesenyapan atau kebisuan guru } \\
\text { (teacher silence): memberikan } \\
\text { waktu senyap }\end{array}$ & $\mathrm{V}$ & $\mathrm{V}$ & $\mathrm{V}$ & $\mathrm{V}$ & $\mathrm{V}$ & $100 \%$ \\
\hline & & $\begin{array}{l}\text { Pergantian posisi guru dalam } \\
\text { kelas dan gerak guru (teacher } \\
\text { movement) }\end{array}$ & $\mathrm{V}$ & - & - & $\mathrm{V}$ & - & $40 \%$ \\
\hline \multirow{4}{*}{2} & \multirow{4}{*}{$\begin{array}{c}\text { Variasi } \\
\text { dalam } \\
\text { penggunaan } \\
\text { media } \\
\text { pembelajaran }\end{array}$} & $\begin{array}{l}\text { Variasi alat atau bahan yang } \\
\text { dapat dilihat (visual aids) }\end{array}$ & $\mathrm{V}$ & $\mathrm{V}$ & $\mathrm{V}$ & $\mathrm{V}$ & $\mathrm{V}$ & $100 \%$ \\
\hline & & $\begin{array}{l}\text { Variasi alat atau bahan yang } \\
\text { dapat didengar (auditif aids) }\end{array}$ & - & - & - & $\mathrm{V}$ & - & $20 \%$ \\
\hline & & $\begin{array}{l}\text { Variasi alat atau bahan yang } \\
\text { dapat diraba, dimanipulasi, dan } \\
\text { digerakkan (motoric) }\end{array}$ & - & $\mathrm{V}$ & - & - & - & $20 \%$ \\
\hline & & $\begin{array}{l}\text { Variasi alat atau bahan yang } \\
\text { dapat didengar, dilihat, dan } \\
\text { diraba }\end{array}$ & - & - & - & - & - & - \\
\hline
\end{tabular}


Lanjutan Tabel 2. Hasil Penampilan Mahasiswa pada Keterampilan Mengadakan Variasi

\begin{tabular}{|c|c|c|c|c|c|c|c|c|}
\hline \multirow{5}{*}{3} & \multirow{5}{*}{$\begin{array}{l}\text { Variasi } \\
\text { dalam pola } \\
\text { interaksi dan } \\
\text { kegiatan } \\
\text { peserta didik }\end{array}$} & $\begin{array}{l}\text { Pola guru-peserta didik: } \\
\text { interaksi sebagai aksi (satu } \\
\text { arah) }\end{array}$ & $\mathrm{V}$ & $\mathrm{V}$ & $\mathrm{V}$ & $\mathrm{V}$ & $\mathrm{V}$ & $100 \%$ \\
\hline & & $\begin{array}{l}\text { Pola guru-peserta didik-guru: } \\
\text { ada balikan (feedback) bagi } \\
\text { guru, tidak ada interaksi antar } \\
\text { peserta didik (komunikasi } \\
\text { sebagai interaksi) }\end{array}$ & $\mathrm{V}$ & $\mathrm{V}$ & $\mathrm{V}$ & - & $\mathrm{V}$ & $80 \%$ \\
\hline & & $\begin{array}{l}\text { Pola guru-peserta didik- } \\
\text { peserta didik: ada balikan bagi } \\
\text { guru, peserta didik saling } \\
\text { membelajarkan }\end{array}$ & - & - & - & $\mathrm{V}$ & - & $20 \%$ \\
\hline & & $\begin{array}{l}\text { Pola guru-peserta didik, } \\
\text { peserta didik-guru, peserta } \\
\text { didik-peserta didik: interaksi } \\
\text { optimal guru dengan peserta } \\
\text { didik, dan peserta didik } \\
\text { dengan peserta didik } \\
\end{array}$ & - & - & - & - & - & - \\
\hline & & $\begin{array}{l}\text { Pola melingkar: setiap peserta } \\
\text { didik mendapat giliran untuk } \\
\text { mengemukakan } \\
\text { pertanyaan/jawaban dan tidak } \\
\text { diperkenankan berbicara dua } \\
\text { kali apabila peserta didik } \\
\text { belum mendapat giliran }\end{array}$ & $\mathrm{V}$ & - & $\mathrm{V}$ & - & $\mathrm{V}$ & $60 \%$ \\
\hline
\end{tabular}

Sumber : Hasil Penelitian, diolah (2017)

Berdasarkan hasil yang dipaparkan pada Tabel 2, dapat disimpulkan bahwa secara keseluruhan, lima orang mahasiswa yang melaksanakan praktik mengajar PPL II di SMAN 5 Banjarmasin, SMKN 1 Banjarmasin, dan MAN 3 Banjarmasin melakukan variasi pada gaya mengajar berupa variasi suara, gerakan tangan untuk memperjelas materi serta memberikan waktu senyap (teacher silence) selama proses pembelajaran. Selain itu, variasi lainnya yang nampak ditampilkan oleh kelima mahasiswa tersebut adalah menggunakan variasi alat atau bahan yang dapat dilihat serta variasi dalam interaksi satu arah.

\section{Hasil Penampilan Mahasiswa PPL II pada Keterampilan Mengadakan Variasi berdasarkan Catatan Lapangan}

Pada saat pelaksanaan observasi mahasiswa yang melakukan praktik mengajar pada PPL II untuk keterampilan mengadakan variasi, peneliti melakukan pencatatan semua informasi yang belum tertera pada lembar observasi. Hasil catatan lapangan dari kelima mahasiswa yang diteliti, disajikan dalam Tabel 3 berikut. 
Tabel 3. Hasil Catatan Lapangan dari Mahasiswa pada Penampilan Mahasiswa

\begin{tabular}{|c|c|c|c|}
\hline No & $\begin{array}{l}\text { Kode } \\
\text { Guru }\end{array}$ & $\begin{array}{l}\text { Tempat } \\
\text { Praktik }\end{array}$ & Hasil Catatan Lapangan \\
\hline \multirow{4}{*}{1} & \multirow{4}{*}{ A } & \multirow{4}{*}{$\begin{array}{l}\text { SMAN } 5 \\
\text { Banjarm } \\
\quad \text { asin }\end{array}$} & $\begin{array}{l}\text { Guru A memiliki volume suara yang cukup lantang ketika } \\
\text { mengajar dikelas, sehingga semua peserta didik dapat } \\
\text { menyimak penjelasan guru dengan baik. }\end{array}$ \\
\hline & & & $\begin{array}{l}\text { Cukup baik dalam memberikan jeda waktu antara memberi } \\
\text { penjelasan dan memberi kesenyapan sejenak ketika } \\
\text { menjelaskan materi }\end{array}$ \\
\hline & & & $\begin{array}{l}\text { Warna yang terdapat pada Power Point sebagai media } \\
\text { pembelajaran yang dipilih terlalu mencolok }\end{array}$ \\
\hline & & & $\begin{array}{l}\text { Pola interaksi yang dibangun belum efektif karena belum } \\
\text { memberi kesempatan kepada semua peserta didik untuk } \\
\text { memberikan tanggapan atau jawaban. }\end{array}$ \\
\hline \multirow[t]{4}{*}{2} & \multirow[t]{4}{*}{ B } & \multirow{4}{*}{$\begin{array}{l}\text { MAN } 3 \\
\text { Banjarm } \\
\quad \text { asin }\end{array}$} & $\begin{array}{l}\text { Guru B memiliki volume suara yang sangat lirih sehingga } \\
\text { harus bekerja keras untuk memusatkan perhatian peserta } \\
\text { didik. Intonasi suara kurang tegas. Peserta didik yang duduk } \\
\text { di bangku belakang kurang jelas mendengar suara guru }\end{array}$ \\
\hline & & & $\begin{array}{l}\text { Kontak pandang terhadap peserta didik kurang. Terlalu } \\
\text { banyak mengarahkan pandangan ke buku yang dipegang } \\
\text { ketika memberikan penjelasan materi }\end{array}$ \\
\hline & & & $\begin{array}{l}\text { Menggunakan realia sebagai media pembelajaran yang dapat } \\
\text { diraba dan dipegang oleh peserta didik }\end{array}$ \\
\hline & & & $\begin{array}{l}\text { Hanya beberapa peserta didik yang aktif berpartisipasi dalam } \\
\text { diskusi }\end{array}$ \\
\hline \multirow{3}{*}{3} & \multirow{3}{*}{$\mathrm{C}$} & \multirow{3}{*}{$\begin{array}{l}\text { MAN } 3 \\
\text { Banjarm } \\
\text { asin }\end{array}$} & $\begin{array}{l}\text { Intonasi suara datar. Terlalu banyak duduk di meja guru } \\
\text { ketika memberikan penjelasan materi kepada peserta didik, } \\
\text { sehingga peserta didik yang duduk di bangku tengah dan } \\
\text { belakang tidak focus dan tidak memperhatikan guru }\end{array}$ \\
\hline & & & $\begin{array}{l}\text { Cukup baik dalam menggunakan Power Point. Warna slide } \\
\text { cukup baik sehingga bisa terbaca hingga ke peserta didik } \\
\text { yang duduk di bangku belakang }\end{array}$ \\
\hline & & & $\begin{array}{l}\text { Pola interaksi guru-peserta didik belum maksimal. Guru } \\
\text { masih mendominasi kelas }\end{array}$ \\
\hline \multirow{3}{*}{4} & \multirow{3}{*}{$\mathrm{D}$} & \multirow{3}{*}{$\begin{array}{l}\text { SMKN } 1 \\
\text { Banjarm } \\
\quad \text { asin }\end{array}$} & $\begin{array}{l}\text { Volume suara cukup nyaring. Pola bicara sedikit terlalu } \\
\text { cepat sehingga beberapa poin penjelasan penting } \\
\text { pembelajaran belum tersampaikan hingga tuntas }\end{array}$ \\
\hline & & & $\begin{array}{l}\text { Menggunakan speaker sebagai media } \\
\text { listening. Kualitas suara speaker cukup } \\
\text { pembelajaran disiapkan dengan matang }\end{array}$ \\
\hline & & & $\begin{array}{l}\text { Pola interaksi guru-peserta didik masih belum terbangun } \\
\text { secara efektif. Guru terlalu banyak mendominasi } \\
\text { pembelajaran sehingga peserta didik hanya duduk } \\
\text { mendengarkan penjelasan guru }\end{array}$ \\
\hline
\end{tabular}




Lanjutan Tabel 3. Hasil Catatan Lapangan dari Mahasiswa pada Penampilan
Mahasiswa
\begin{tabular}{|c|c|c|l|}
\hline 5 & \multirow{2}{*}{ E } & $\begin{array}{c}\text { SMKN 1 } \\
\text { Banjarm } \\
\text { asin }\end{array}$ & $\begin{array}{l}\text { Volume suara cukup nyaring, kontak mata kepada seluruh } \\
\text { peserta didik cukup baik, akan tetapi belum mampu } \\
\text { membuat seluruh peserta didik terfokus pada pembelajaran. }\end{array}$ \\
\cline { 3 - 4 } & $\begin{array}{l}\text { Pola interaksi guru-peserta didik cukup baik. Peserta didik } \\
\text { lebih aktif dikarenakan mereka sudah familiar dengan topic } \\
\text { materi yang diberikan }\end{array}$ \\
\hline
\end{tabular}

Sumber : Hasil Penelitian, diolah (2017)

Berdasarkan hasil catatan lapangan yang terdapat pada Tabel 3 diatas, dapat disimpulkan bahwa sebagian besar mahasiswa yang melaksanakan praktik mengajar pada PPL II sudah banyak mengadakan variasi selama proses pembelajaran didalam kelas. Akan tetapi, variasi-variasi yang dilakukan masih mengandung beberapa kekurangan serta belum semua variasi dapat dilakukan oleh kelima mahasiswa yang diteliti pada penelitian ini.

\section{Pembahasan}

Keterampilan dasar mengajar merupakan keterampilan yang mutlak harus dikuasai seorang pengajar. Hal ini dikarenakan keterampilan dasar mengajar tidak hanya berorientasi pada produk akhir untuk mengevaluasi baik tidaknya guru dalam mengajar sehingga menentukan bagus tidaknya prestasi peserta didik. Akan tetapi, keterampilan dasar mengajar juga berorientasi pada proses pembelajaran dimana situasi, lingkungan, kondisi sekitar lokasi pembelajaran harus menunjang keberhasilan kegiatan belajar mengajar. Kemampuan mengadakan variasi yang disebut juga dengan variation stimulus merupakan salah satu kemampuan dasar mengajar yang mutlak harus dikuasai oleh guru. Variasi dalam mengajar menjadi penting dilakukan dengan pertimbangan bahwa suasana mengajar yang kaku dan monoton akan membuat peserta didik tidak memiliki semangat belajar yang tinggi. Sebagai bagian dari salah satu keterampilan dasar mengajar, mahasiswa yang mengambil program studi pendidikan dan keguruan sudah selayaknya menguasai variasi-variasi yang perlu dilakukan didalam kelas.

Semua keterampilan dasar mengajar memerlukan latihan terus menerus. Dalam hal melatih keterampilan dasar mengajar secara rutin, mahasiswa Program Studi Pendidikan Bahasa Inggris STKIP PGRI Banjarmasin mengimplementasikannya dalam Praktik Pengalaman Lapangan (PPL) I dan II. Salah satu keterampilan dasar mengajar yang implementasinya terlihat pada penelitian ini yaitu mahasiswa menampilkan keterampilan mengadakan variasi. Hasil penelitian ini menunjukkan bahwa sebagian besar mahasiswa yang diteliti sudah menampakkan variasi dalam proses belajar mengajar. Pertama, sebagaian besar mahasiswa sudah menampakkan gaya mengajar dalam hal penggunaan variasi suara, gerakan tangan dan badan untuk memperjelas materi, serta memberikan waktu senyap untuk memberi jeda dalam penyampaian materi. Selain itu, semua mahasiswa yang diteliti menggunakan variasi dalam penggunaan media pembelajaran yang sama yaitu menggunakan alat atau bahan yang dapat dilihat (visual aids). Hasil yang terakhir adalah sebagian besar mahasiswa yang diteliti melakukan variasi dalam pola interaksi yang cenderung sama yaitu 
interaksi satu arah dan pola balikan namun belum berjalan maksimal dalam interaksi antar peserta didik.

Pada proses pembelajaran yang dilaksanakan, tiga dari lima orang $(60 \%)$ mahasiswa yang diteliti menggunakan variasi suara, baik dalam bentuk variasi nada suara, volume suara, maupun kecepatan berbicara. Nada suara guru menjadi penting untuk diperhatikan karena guru merupakan tokoh utama yang penjelasannya akan didengar oleh peserta didik. Apabila guru memiliki intonasi suara yang baik, tegas, dan mendalam, maka peserta didik akan memperhatikan dengan baik dan fokus. Hal ini juga senada dengan hasil pada catatan lapangan dimana terdapat dua orang guru yang memiliki volume suara lirih dan intonasi suara yang datar berdampak pada tidak fokusnya peserta didik karena tidak dapat mendengarkan suara guru dengan jelas. Menurut Delima dkk (2015:6), volume, intonasi, maupun nada suara dari seorang guru turut menentukan daya tangkap peserta didik. Setiap peserta didik memiliki daya tangkap yang berbeda terhadap penjelasan guru, sehingga guru harus memiliki kemampuan mengatur dan mengolah suara sesuai dengan kebutuhan peserta didik dan kondisi kelas.

Selain variasi suara, $100 \%$ mahasiswa yang diteliti menampakkan variasi gerakan tangan dan badan untuk memperjelas materi. Gerakan tangan dan badan yang dilakukan dalam mengajar sangat penting diperhatikan guru. Guru merupakan tokoh sentral dalam penyampaian materi. Penjelasan lisan guru dalam menyampaikan materi tidak akan memberi makna apapun terhadap pemahaman peserta didik bila tidak didukung dengan gerakan tangan dan badan. Guru yang hanya duduk di meja guru dalam menjelaskan materi mengisyaratkan bahwa guru tersebut tidak memiliki kesadaran akan pentingnya memberikan penekanan materi dengan melakukan variasi gerakan tangan dan badan. Variasi dengan gerakan tangan, mata, kepala, dan badan akan memperkuat ekspresi guru, sehingga peserta didik dapat focus menyimak materi dengan seksama (Asril,2013:88).

Dalam hal melakukan variasi kesenyapan (teacher silence), keseluruhan mahasiswa yang diteliti melakukan kesenyapan yang bertujuan untuk menarik perhatian peserta didik agar tetap tertuju pada penjelasan guru. Ketika guru menyampaikan materi, lalu terdiam sejenak selama beberapa menit, akan membuat peserta didik penasaran akan perubahan situasi ini yang terjadi ditengah-tengah kefokusan mereka menyimak penjelasan materi. Hal ini tentu menstimulasi mereka untuk tetap mengarahkan pandangan terhadap guru, sehingga mereka tetap menyimak penjelasan materi dengan penuh perhatian.

Pada hasil penelitian ini, variasi lain yang nampak dilakukan oleh subyek yang diteliti adalah variasi dalam penggunaan media pembelajaran. $100 \%$ mahasiswa yang diteliti menggunakan laptop, LCD, dan menyampaikan materi dalam bentuk Power Point. Penggunaan media semacam ini termasuk dalam media yang dapat dilihat peserta didik secara visual (visual aids). Mereka menggunakan tampilan Power Point dengan persiapan yang cukup baik, sehingga tampilan materi bisa terlihat hingga peserta didik yang duduk di bangku paling belakang. Laptop, LCD, dan Power Point merupakan seperangkat media yang sederhana dan cukup familiar. Tidak hanya guru yang bisa mengoperasikannya, peserta didik pun dapat mengoperasikan penggunaannya sehingga dapat dengan mudah dipilih sebagai alat bantu pembelajaran. 
Puspayanti dkk (2013:18-19) mengemukakan bahwa Power Point sebagai media visual memberikan tampilan materi yang menarik karena adanya permainan warna, huruf, dan animasi. Selain itu, hampir seluruh sekolah praktik pada penelitian ini sudah melengkapi fasilitas pembelajaran dengan LCD yang terpasang permanen di setiap kelas sehingga media pembelajaran visual dapat digunakan dengan mudah dan efisien.

Variasi terakhir yang nampak dilakukan dalam penelitian ini adalah variasi dalam pola interaksi dan kegiatan peserta didik. Menurut Karuru (2018:6), dalam proses pembelajaran, interaksi antara guru dan peserta didik merupakan kegiatan penyampaian ilmu pengetahuan (transfer of knowledge) dan penyampaian nilai-nilai pengetahuan (transfer of values) untuk mencapai tujuan pembelajaran. Pada penelitian ini, keseluruhan subyek yang diteliti menampilkan variasi interaksi yang sama yaitu interaksi satu arah dari guru kepada peserta didik. Variasi ini cenderung dilakukan karena guru masih menjadi aktor utama dalam proses pembelajaran. Interaksi satu arah ini bisa berjalan dengan baik apabila peserta didik cukup aktif. Akan tetapi, interaksi dengan pola satu arah ini juga memiliki kelemahan. Guru yang terlalu mendominasi pembelajaran tidak akan menstimulasi peserta didik untuk berpikir kritis dan mandiri. Seluruh peserta didik akan tergantung kepada penjelasan guru tanpa ada dorongan untuk mencari sumber belajar yang lain. Guru dianggap sebagai satu-satunya sumber informasi dikelas, tetapi guru juga harus berperan sebagai pembimbing, moderator, maupun fasilitator.

Dalam hal variasi kegiatan peserta didik, keseluruhan mahasiswa yang praktik mengajar cenderung melakukan kegiatan yang sama yaitu diskusi kelompok. Berdasarkan hasil yang direkam pada catatan lapangan, peserta didik sudah menunjukkan partisipasi dalam diskusi walaupun belum sepenuhnya optimal. Beberapa peserta didik masih mendominasi diskusi serta kesempatan agar semua peserta didik memberikan jawaban atas pertanyaan dalam diskusi juga belum merata. Akan tetapi, terdapat satu kegiatan diskusi yang berjalan dengan baik karena peserta didik topik sudah familiar dengan topic yang didiskusikan. Hal ini mengindikasikan bahwa melakukan variasi kegiatan peserta didik perlu mempertimbangkan factor tertentu. Latip (2016:21-27) mengemukakan bahwa latar belakang sekolah dan peserta didik yang berbeda, sarana prasarana sekolah, motivasi peserta didik dalam belajar, scenario pembelajaran yang harus disiapkan guru, serta keterampilan guru dalam mengimplementasikan pola pembelajaran yang berpusat pada peserta didik merupakan beberapa factor yang perlu dipikirkan dan dipertimbangkan oleh guru dalam melakukan variasi kegiatan peserta didik pada proses pembelajaran.

Berdasakan paparan diatas, dapat diketahui bahwa selain mengimplementasikan beberapa variasi, masih ditemukan banyaknya variasi pembelajaran yang belum dilakukan oleh semua mahasiswa yang diteliti pada penelitian ini. Kondisi sekolah dan peserta didik yang berbeda di setiap sekolah praktik, kurangnya menggali referensi yang maksimal dari mahasiswa praktik untuk mencari sumber informasi terkait ide dan kreativitas dalam merancang kegiatan pembelajaran, serta faktor mental dan emosional yang dimiliki mahasiswa praktik dalam menghadapi dan mengelola situasi di kelas, menjadi beberapa catatan tambahan yang perlu evaluasi berkelanjutan dalam usaha menghasilkan calon guru yang terampil dan profesional. Keterampilan mengadakan variasi memerlukan latihan terus menerus 
sebagai upaya melatih salah satu keterampilan dasar mengajar yang kelak diperlukan oleh calon guru dalam mengimplementasikan kegiatan belajar mengajar yang optimal dan efektif.

\section{KESIMPULAN DAN SARAN}

Hasil penelitian ini menyimpulkan bahwa keterampilan mengadakan variasi yang dilakukan oleh mahasiswa Program Studi Pendidikan Bahasa Inggris STKIP PGRI Banjarmasin pada Praktik Pengalaman Lapangan (PPL) II di SMAN 5 Banjarmasin, MAN 3 Banjarmasin, dan SMKN 1 Banjarmasin adalah penggunaan variasi suara, gerak dan mimik, kesenyapan guru, variasi dalam menggunakan media yang dapat dilihat, serta variasi dalam pola interaksi satu arah dari guru kepada peserta didik. Akan tetapi, masih banyak keterampilan variasi lain yang belum diimplementasikan oleh mahasiswa praktik, seperti variasi kontak pandang, pemusatan perhatian siswa, variasi menggunakan media pembelajaran non-visual, serta belum terlihat adanya interaksi dua arah maupun multi arah antara guru dan peserta didik yang efektif dalam proses pembelajaran. Faktor internal dari diri mahasiswa praktik itu sendiri serta faktor eksternal yang berasal dari sekolah praktik dan peserta didik menjadi faktor penentu keberhasilan proses praktik mengajar mahasiswa agar mereka mendapatkan pengalaman latihan yang bermakna.

Berdasarkan kekurangan yang masih terlihat pada Praktik Pengalaman Lapangan (PPL) II mahasiswa dalam implementasi keterampilan mengadakan variasi pada penelitian ini, maka diperlukan latihan terus menerus untuk mengimplementasikan keterampilan dasar mengajar secara perlahan-lahan. Mengajar adalah kegiatan yang sangat kompleks. Persiapan, kesabaran, dan kreativitas dari calon guru dalam merancang scenario pembelajaran mutlak diperlukan. Evaluasi bersama antara dosen yang membimbing PPL, guru pamong di sekolah praktik, kepala sekolah, serta mahasiswa praktik itu sendiri diharapkan dapat saling memberikan feedback dan masukan berkelanjutan dalam rangka menghasilkan calon guru yang terampil dan terlatih dalam melaksanakan proses belajar mengajar.

\section{DAFTAR PUSTAKA}

Ambarawati, M. 2016. Analisis Keterampilan Mengajar Calon Guru Pendidikan Matematika pada Mata Kuliah Micro Teaching. Jurnal Pedagogia, 5(1): 81-90

Asril, Z. 2013. Micro Teaching Disertai dengan Pedoman Pengalaman Lapangan. Jakarta: Rajawali Pers.

Delima, Rustiyarso, dan Salim, I. 2015. Persepsi Siswa tentang Variasi Gaya Mengajar Guru Sosiolog di SMA Islamiyah Pontianak. Jurnal Pendidikan dan Pembelajaran, 4(11): 1-9

Helmiati. 2013. Micro Teaching. Melatih Keterampilan Dasar Mengajar. Yogyakarta: CV. Aswaja Pressindo.

Karuru, P. 2018. Persepsi Peserta Didik terhadap Interaksi Pembelajaran IPA Fisika di SMP Negeri 3 Mengkendek. Jurnal Neutrino, 1(1): 5-16

Latip, A. 2016. Faktor-Faktor Pendukung dan Penghambat Pembelajaran Mata Pelajaran IPS di SMP. Jurnal Pendidikan Profesional, 5(2): 19-27 
Pedoman Praktik Pengalaman Lapangan. 2017. Banjarmasin: STKIP PGRI Banjarmasin

Puspayanti, Saharudin, dan Budiyono, H. 2013. Pengaruh Media Pembelajaran Berbasis Power Point dan Kecerdasan Emosional terhadap Kemampuan Menulis Deskriptif Siswa Kelas VII SMPN 8 Muaro Jambi. Tekno-Pedagogi, 3(2): $12-24$

Suwarna, Gufron, A., Sofyan, H., dkk. 2013. Modul Pelatihan Pengembangan Keterampilan Dasar Teknik Instruksional (Pekerti). Yogyakarta: LPPM UNY 